\title{
Start of the Journal of Family Practice
}

\author{
John P. Geyman, MD
}

\section{(J Am Board Fam Med 2021;34:668-669.)}

In 1969 , when family practice was recognized as the 20th specialty in American medicine, there was little tradition for research and no forum for reporting original work in the field. GP, the monthly journal of the American Academy of General Practice, was derivative in nature with review articles drawn from clinical work in other specialties.

At that time, I had been a GP in rural practice in Mount Shasta, California, for 6 years. As family practice residency programs were being established across the country, I felt an urgent need to get involved in their development. In 1969, I accepted an offer to return to Santa Rosa, California, and to convert the 2-year general practice residency at Sonoma County Hospital, where I had trained, to a 3 -year family practice residency. That was accomplished under a Regional Medical Programs grant, including setting up an affiliation with the University of California San Francisco.

It was there that I published my first book in 1971, The Modern Family Doctor and Changing Medical Practice. After 2 rejections, it was published by David Stires, president of Appleton-CenturyCrofts, who had grown up in a small town in Ohio where his father was a general practitioner.

The urgent need for a scientific journal in family practice was obvious to me. In 1973, when at the University of California Davis, I proposed the idea of such a journal to David. He immediately saw its need and potential, so we embarked on making it happen. We convened an organizational meeting in San Francisco in 1973, including some of the early

From the University of Washington, Seattle.

Funding: None.

Conflict of interest: None.

Corresponding author: John P. Geyman, MD, University of Washington, 34 Oak Hill Drive, Friday Harbor, WA 98250 (E-mail: jgeyman@uw.edu).

\section{See Related Article on Page 477.}

leaders in family practice. There was unanimous agreement that we should proceed. I was confirmed as editor of The Fournal of Family Practice ( $F F P$ ), and soon thereafter our editorial office was established in my office at Davis.

We had 7 members of our original editorial board and 13 members of our multidisciplinary editorial advisory board. Together, we identified potential people and projects that would be of interest and value to our readership in our developing discipline. As we worked to get the word out of our existence, we invited some articles, and it was always exciting to receive unsolicited articles for review. Peer reviews were the old-fashioned kindpencil, article, and regular mail. Together with my editorial assistant, we had a blackboard with chalk listing contents of future issues, which could readily be adapted to the flow of manuscripts.

It was exciting to see our manuscript flow increase, especially in the early years. The quality of writing and content improved steadily. It was always difficult to reject articles, especially when our editorial team knew some of the authors personally. To meet the needs of our fledgling specialty, we mapped out useful categories for articles, including clinical, educational, and research articles, together with Family Practice Grand Rounds and Family Practice Forum for exchange of opinion. Our content had to be critically peer reviewed and meet 4 criteria: new, true, comprehensible, and important to our readership.

Initially, we decided to publish quarterly, with the first issue in May 1974. We started on a subscription basis but soon found that would not cover start-up costs, either for the publisher or the editorial office. We then shifted to controlled circulation, whereby we mailed copies to all practicing general and family physicians in the country. That allowed us to accept advertising, which developed quickly, but we retained full editorial independence without conflicts of interest. 
Because of our readership of all general/family physicians in the country, we were under pressure to intersperse ads within articles, which we resisted from the beginning. The biggest pressure came from drug companies that put together "supplements" to our journal without any editorial involvement on our part. They would hold a meeting just before a major national family practice meeting, such as the American Academy of Family Physicians, invite speakers of their own choice, and then come to us with that package proposal. We rejected all of them out of hand during my tenure as editor. There was a change of publishers 4 times over those years, with each continuing that pressure and hoping to build $\mathcal{F F P}$ as a cash cow.

My wife, Gene, and I moved full-time to San Juan Island, 85 air miles from Seattle, in 1990, when I joined a 4-family physician group serving our island of 7000 people. That is when I left the editorship of
FFP after 17 years, assuming that the distance from Seattle and time pressures of practice would preclude continuing on. I changed my mind, however, when soon thereafter, I was asked to edit the fournal of the American Board of Family Practice. I had just purchased a small float plane and found that I could fly down to Seattle in 45 minutes, land on Portage Bay adjacent to the medical school, and walk to work to the same editorial office I had just left!

It was rewarding to continue editing with $7 A B F P$ for another 13 years.

That total of 30 years editing our specialty's journals was a privilege and a highlight of my life. It is gratifying to see $\mathcal{F F P}$ 's successful continuance in our field after all these years.

To see this article online, please go to: http://jabfm.org/content/ 34/3/668.full. 